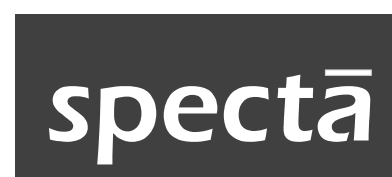

Journal of Photography,

Arts, and Media

Volume 1 Nomor 2

November 2017: 133-140

\section{REOG TULUNGAGUNG DI SANGGAR TARI DANDHANG SAPUTRO MUDHO DALAM FOTOGRAFI DOKUMENTER}

\author{
Abdul Kholid \\ Edial Rusli* \\ Zulisih Maryani** \\ Fakultas Seni Media Rekam, Institut Seni Indonesia (ISI) Yogyakarta \\ Surel: edial_rusli@yahoo.com
}

\begin{abstract}
Abstrak
Penciptaan karya berorientasi pada sosok seniman Suratmin Wibisono sebagai dasar acuan atau kerangka cerita pemahaman tentang eksistensi Reog Tulungagung yang dikembangkan di sanggar miliknya. Reog Kendhang sebelum diubah nama menjadi Reog Tulungagung adalah sebuah tarian penggambaran prajurit kerajaan yang memiliki latar belakang yang bersinggungan dengan masyarakat Tulungagung. Dandhang Saputro Mudho merupakan sanggar seni yang mengembangkan serta melestarikan kesenian tari tradisional yang telah ditetapkan menjadi ikon Kabupaten Tulungagung ini. Metode EDFAT digunakan dalam pengambilan gambar. Metode entire untuk pengambilan menyeluruh, detail dalam pengamatan bagian tertentu, frame sebagai cara pengemasan foto yang terfokus, angle pengambilan sudut yang menarik, serta time untuk pemvisualisasian pergerakan objek. Selain itu, bentuk potret digunakan untuk mengenalkan objek secara personal. Foto-foto dokumenter yang diciptakan berjumlah 20 karya foto tunggal. Setiap karya disusun sedemikian rupa sehingga membentuk sebuah narrative text visual. Hasil pemilihan karya kegiatan yang paling banyak adalah kegiatan yang dilakukan di lingkungan sanggar Dandhang Saputro Mudho. Hal ini dikarenakan sanggar bukan hanya menjadi pusat berkegiatan seni, tetapi juga tempat anggota sanggar bermain dan bersosialisasi. Selain itu, lokasi sanggar yang juga berdekatan dengan rumah Suratmin dan beberapa anggota sanggar.
\end{abstract}

Kata Kunci: reog tulungagung, sanggar tari dandhang saputro mudho, fotografi dokumenter

\begin{abstract}
Reog Tulungagung at Dandhang Saputro Mudho Dance Studio in Documentary Photography. Reog art is a famous traditional arts in East Java. Reog Tulungagung is the art of traditional dance that has long existed but has only known by the public in recent years. Reog Drums, before it changed its name to Reog Tulungagung, is a dance depiction of royal soldiers who have a background relating to the public of Tulungagung. Dandhang Saputro Mudhois an art studio that develops and preserves the art of traditional dance that has been set become an icon of Tulungagung District. The method of EDFAT is used in taking photographs. Entire method is for making a thorough, detailed in the observation of certain parts, the frame as a way of packaging a focused picture, angle making an interesting angle, as well as the time for the depiction of movement of the object. EDFAT is used in photography to provide information visualy. Each of the photographic work is arranged to help form of 20 photos and to make a visual narrative text. The result shows that most activities are done in the surrounding neighborhood of Dandhang Saputro Modho. Technology media of photography can be seen as an attempt for reog to introduce Tulungagung which is able to bridge the preservation of reog in accordance with the reality without having to look at it directly. The result of the research is that each documentary film made Photography as a mass media that can be reproduced infinitely better through exhibitions, print and electronic world provides capable contributed widely enjoyed.
\end{abstract}

Keywords: Reog Tulungagung, studio dance dandhang saputro mudho, documentary photography

\footnotetext{
*Dosen di Program Studi Fotografi, Fakultas Seni Media Rekam, ISI Yogyakarta

${ }^{*}$ Dosen di Program Studi Fotografi, Fakultas Seni Media Rekam, ISI Yogyakarta
} 


\section{PENDAHULUAN}

Seni tari adalah salah satu kesenian rakyat yang masih banyak dinikmati oleh masyarakat dari zaman dahulu hingga sekarang. Seni tari merupakan seni yang dapat dicerap melalui indera penglihatan, dimana keindahannya dapat dinikmati dari gerakangerakan tubuh, terutama gerakan kaki dan tangan, dan ritme-ritme yang teratur, yang diiringi irama musik yang dicerap melalui indera pendengaran (Bahari, 2014:57). Nilainilai yang terkandung dari setiap gerakannya, pakaian yang digunakan, dan atribut yang dipakai, juga menjadi identitas dari setiap seni tradisional. Selain itu, cerita sejarah atau historis yang melatarbelakangi terlahirnya kesenian tersebut bisa saja memiliki hubungan atau masih menjadi bagian dari babad dari suatu daerah.Maka dari itu, beberapa dari kesenian tari menjadi ikon khas suatu daerah tempat tari tersebut diciptakan, seperti halnya kesenian reog.

Reog adalah salah bentuk kesenian tari tradisional yang sudah tidak asing lagi bagi masyarakat umum, baik di Jawa maupun di Indonesia, meskipun awal mulanya reog hanya dikenal oleh masyarakat Ponorogo, Trenggalek dan Tulungagung. Akan tetapi, istilah reog yang dikenal masyarakat saat ini selalu diidentikkan dengan Reog Ponorogo yang khas dengan sebuah topeng besar berbentuk dua kepala hewan, yakni kepala harimau dan bulu burung merak yang diiringi dengan musik dari alat musik tradisional Jawa karena banyak sekali dikembangkan diberbagai daerah dan sering dipertunjukkan dalam berbagai acara kegiatan. Sementara nama Reog Kendhang yang berasal dari Kabupaten Tulungagung (sebelum diubah menjadi Reog Tulungagung) kurang dikenal oleh masyarakat. Hingga saat ini belum banyak masyarakat diluar Tulungagung mengetahui Reog Kendhang, bahkan tidak semua masyarakat Tulungagung mengetahui bahwa Reog Kendhang adalah tarian asli Tulungagung.

Meskipun tari adalah salah satu seni yang tertua, dalam masalah pembuatan dokumentasinya tari mengalami perjalanan sejarah yang pendek (Royce, 2009:42). Reog Kendhang termasuk kesenian tradisional yang sudah lama ada, namun perkembangan dan pelestarian dari kesenian Reog Kendhang ini tergolong lamban. Masih belum banyak data dan dokumen yang membahas Reog Kendhang karena kesenian ini baru mendapat perhatian pemerintah setempat pada pertengahan tahun 2009. Tidak dapat dipungkiri, jika suatu saat kesenian Reog Kendhang ini akan dikembangkan dan diajarkan di daerah lain sehingga sangat dibutuhkan bentuk pendokumentasian dari kesenian ini yang bukan hanya berupa artikel atau dokumen berupa tulisan, tetapi juga data berupa data visual foto yang dapat menjadi bukti atau data yang valid. Dengan demikian, rupa visual dari bentuk asli kesenian ini tidak akan hilang asal-usulnya, ciri khasnya ataupun makna dari kesenian ini meskipun berkembang di daerah lain. Oleh karena itu, upaya pembentukan sebuah karya fotografi dokumenter yang akan diciptakan disalah satu sanggar di Tulungagung ini dapat menjadi data yang menunjukkan potret dari Reog Tulungagung ini. Selain itu, dapat menjadi media dalam upaya pengenalan dengan tujuan melestarikan kesenian Reog Tulungagung.

Sebagai salah satu kota yang sedang berkembang, tentu menjadi perhatian segala aspek bidang yang mampu mendukung berkembangnya suatu daerah, dan salah satunya adalah bidang pariwisata dan kesenian budaya khas yang bisa menjadi ikon. Dalam hal ini adalah kesenian tari Reog Tulungagung, dan tentu saja untuk mengetahui ikon tersebut harus diketahui terlebih dahulu apa Reog Tulungagung itu, apa saja instrument yang terdapat dalam tarianberikut maksudnya dan bagaimana peranan atau upaya 
Sanggar Tari Dandhang Saputro Mudho dalam melestarikan Reog Tulungagung? Lalu bagaimana cara memvisualisasikan kesenian ini dalam sebuah karya fotografi sehingga dapat menjadi bentuk media komunikasi baru dalam memperkenalkan kesenian reog yang mudah dipahami oleh penikmat atau khalayak? Maka dari itu, penelusuran dan penciptaan ini menjadi penting dalam memahami perkembangan kesenian tersebut.

Dari penciptaan karya fotografi ini akan dapat mengetahui dan mengenal keunikan dan ciri khas dari Reog Tulungagung dan seperti apa cara yang dilakukan di Sanggar Tari Dandhang Saputro Mudho dalam upaya melestarikan dan memperkenalkan Reog Tulungagung untuk mendapatkan eksistensinya saat ini. Selain itu, dapat belajar mengenai kesenian yang memang belum banyak dikenal masyarakat luas mulai dari sejarah, cerita dari bentuk tarian dan menambah daftar ragam kesenian tradisional baru yang salah satunya berasal dari Tulungagung ini.

\section{PEMBAHASAN}

Tahapan rancangan penciptaan yang perlu dilakukan dalam penciptaan foto dokumenter ini adalah:

Pemilihan topik. Merupakan bahasan utama mengenai sesuatu yang akan dijadikan bahan dalam penciptaan foto dokumenter ini. Pemilihan topik karya dokumenter tentang kebudayaan seperti kesenian tradisional Reog Tulungagung ini dilatarbelakangi oleh ketertarikan penulis tentang kesenian tari karena faktor kedekatan (proximity) dengan penulis yang kurang begitu dikenal, pendokumnetasian kesenian tari yang lambat, dan juga belum ada yang mengangkat topik ini secara mendalam dari aspek fotografi.

Setelah mengetahui topik apa yang akan diambil, selanjutnya mencari referensi dari karya-karya terdahulu yang memiliki kesamaan objek lalu mempertimbangkan masalah dan pertanyaan-pertanyaan apa yang sesuai dengan topik yang akan diambil.

Setelah mengetahui topik dan masalah apa yang akan diambil, selanjutnya pemilihan lokasi penciptaan. Sanggar Tari Dandhang Saputro Mudho menjadi lokasi objek penciptaan karya foto dokumenter. Pemilihan lokasi ini dikarenakan sanggar ini merupakan satusatunya sanggar tari di Tulungagung yang mengembangkan dan melestarikan Reog Tulungagung di luar instansi akademik formal berupa kegiatan ektrakurikuler.

\section{a. Pengumpulan Data}

Mengumpulkan data merupakan bagian yang penting dalam penelitian. Pengumpulan data yang dilakukan untuk penciptaan ini adalah observasi, wawancara, dan studi pustaka. Observasi merupakan proses yang sangat penting dalam proses penciptaan karya ini. Melalui metode ini dapat diperoleh gambaran tentang bentuk visual, penampilan dari seorang penari reog secara menyeluruh dalam suatu pementasan atau proses dibelakangnya. Kegiatan ini dilakukan di Sanggar Tari Dandhang Saputro Mudho di Tulungagung. Observasi ini bertujuan untuk mengamati secara langsung bagaimana keadaan atau kondisi Reog Tulungagung di dalam pertunjukan kesenian tradisional dan di dalam sanggar tersebut.

Wawancara dilakukan agar dapat mengumpulkan data yang luput dari pengamatan langsung maupun dari dokumen atau literatur yang didapat. Yang menjadi narasumber wawancara dalam penciptaan ini adalah Kepala Dinas Kebudayaan Tulungagung, ketua sanggar, pelatih sanggar, para penari sanggar dan masyarakat sekitar sanggar. Selain itu juga digunakan metode studi pustaka, metode ini dilakukan dengan mencari dan membaca tulisan-tulisan yang membahas tentang tari tradisional reog. 


\section{Eksplorasi}

Kedekatan menjadi hal utama dalam membuat fotografi dokumenter. Untuk dapat membuat karya yang natural dan apa adanya, diperlukan sebuah kedekatan secara emosional antara penulis dan subjek sehingga tidak terjadi kecanggungan dan berjarak pada saat eksekusi. Dalam hal ini, dilakukanlah pendekatan dengan ketua sanggar, pelatih sanggar, para penari sanggar, dan masyarakat sekitar sanggar. Selain itu, dalam beberapa kesempatan selama proses penciptaan berlangsung, penulis tinggal, menginap di sanggar bersama mereka sehingga memudahkan penulis dalam pencarian data dan pendekatan untuk pengambilan objek-objek foto di lapangan. Kedekatan hubungan inilah yang akan sangat membantu dalam proses penciptaan karya foto dokumenter ini.

\section{Eksperimentasi}

\section{a. Pemilihan ISO}

\section{International Standart Organization} (ISO)adalah satuan untuk mengukur kepekaan sensor kamera dalam menangkap cahaya. Semakin tinggi ISO yang digunakan akan semakin sensitif terhadap cahaya, begitu pula sebaliknya. Pemilihan ISO yang digunakan sangat tergantung dengan situasi dan kondisi saat melakukan eksekusi pemotretan pada objek. Pembuatan karya ini menggunakan pemilihan rentang ISO yang beragam, mulai dari ISO 100-3200. Pemakaian ISO rendah lebih banyak digunakan karena sebagian besar pemotretan dilakukan pada siang hari atau menggunakan cahaya bantuan dari flash karena keberadaan cahaya yang minim. Pemakaian ISO tinggi hanya dilakukan saat pertunjukan agar dapat menangkap gambar pada intensitas cahaya rendah.

b. Ruang Tajam (Depth of Field)

Depth of Fieldatau ruang tajam adalah wilayah ketajaman gambar yang dapat ditangkap oleh lensa dan terekam pada film atau sensor digital kamera (Gani dan Kusumalestari, 2013:33). Ruang tajam sendiri ditentukan oleh besar kecilnya pemilihan dan pemakaian diafragma pada kamera, jarak antara kamera dengan objek, focal length, dan proses editing. Ruang tajam sangat memengaruhi focus of interest dalam suatu karya foto. Pemakaian DOF sempit lebih banyak digunakan untuk memisahkan objek dari benda disekitarnya dengan menjadikan foreground atau background sehingga terfokus pada objek yang dipilih, seperti potret penari atau pemilik sanggar dan detail. Penggunaan DOF luas lebih banyak digunakan untuk pengambilan secara entire agar menampilkan situasi keseluruhan di lokasi. Selain itu, juga mengambil fokus keseluruhan pada penari saat pertunjukan dengan teknik slow speed.

c. Komposisi

Dalam dunia fotografi diartikan sebagai penempatan atau penyusunan bagian-bagian sebuah gambar untuk membentuk kesatuan dalam sebuah bidang tertentu sehingga enak dipandang (Nugroho, 2006;78). Penempatan objek utama dan pendukung dalam membuat sebuah komponen gambar menentukan keartistikan saat dipandang. Peletakan objek utama berada di bagian tengah, tepi bingkai atau sepertiga bidang merupakan aspek yang harus diperhatikan ketika akan mengambil atau menekan rana. Dalam pembuatan karya ini lebih banyak memakai komposisi diagonal untuk membuat sebuah gambar terlihat dinamis dengan penempatan objek yang lebih sering diposisikan disepertiga bidang atau rules of thirdagar sebuah objek 
yang menunjukan situasi sehingga tidak memunculkan kesan kaku dan mati.

\section{d. Angle}

Angle atau arah sudut pandang memiliki peran penting dalam memunculkan cerita dan membuat sebuah kesan pada sebuah gambar. Pembuatan karya ini lebih banyak memakai lensa wide dengan sudut pandang yang cukup luas sehingga dapat menangkap keseluruhan dari lokasi termasuk objek pada suatu peristiwa yang dapat menceritakan sistuasi yang sedang terjadi. Selain itu, panjang focal leght yang relative pendek membuat pengambilan beberapa gambar harus dilakukan dalam jarak dekat sehingga akan memunculkan kesan kedekatan danpembaca melihat kesenian ini secara dekat. Selain itu, arah pengambilan gambar yang banyak dipakai adalah high angle atau bird eye sehingga menampilkan gambar yang terlihat diambil dari atas. Pengambilan eye level atau sejajar membuat kita melihat secara wajar dengan objek juga dipilih agar pembaca melihat kesenian ini seperti biasa mereka melihat dalam keseharian.

e. Proses Perwujudan

Alat dan bahan sangat diperlukan dan menjadi faktor penting yang harus ada dalam pembuatan suatu karya fotografi. Alat adalah benda yang dipakai untuk mengerjakan sesuatu (Tim Penyusun Kamus Besar Bahasa Indonesia,2008:36) dan bahan adalah sesuatu yang dapat dipakai atau diperlukan untuk tujuan tertentu (Tim Penyusun Kamus Besar Bahasa Indonesia,2008:114). Fotografi sebagai metode yang dipilih dalam proses penyampaian atau media perantara tidak terlepas dari dampak kemajuan ilmu pengetahuan dan teknologi modern. Dalam perkembangannya, banyak sekali teknologi yang dikembangkan untuk dapat membantu dan mempermudah pekerjaan, begitu pula dengan teknologi fotografi yang memberikan banyak pilihan alat bantu selain dari teknologi kamera dan lensa itu sendiri. Oleh karena itu, dalam pembuatan karya fotografi dokumenter alat dan bahan yang dipakai selama proses pembuatan karya meliputi:Memory Card; Notebook; Kamera; Card Reader; Hard Disk; LensaCanon 24-70mm f/2.8; LensaTokina 11-16mm f/2.8; Tripod; Flash.

b. Hasil Penciptaan dan Pembahasan Karya

Foto anggota Dandhang Saputro Mudho (gambar 1) dengan pakaian Reog Tulungagung saat pekan seni menyambut HUT Kota Nganjuk. Reog Tulungagung merupakan kesenian yang menjadi ikon tari tradisional Tulungagung sejak tahun 2010. Pakaian penari Reog merupakan penggambaran seorang prajurit yang menari membawa kendhang sebagai ekspresi diri ketika membawa persembahan saat melamar Dewi Kilisuci. Penari haruslah berjumlah enam atau kelipatan, dan dibantu dengan yogo yang memainkan gong, selompret, dan kenong.

Karya foto ini menunjukkan potret penari Reog Tulungagung yang berada di Sanggar Tari Dandhang Saputro Mudho yang memang beberapa ornamennya sudah diganti agar terlihat lebih menarik, namun tetap memiliki makna yang sama. Keberadaan tulisan dibanner menunjukkan kontribusi sanggar

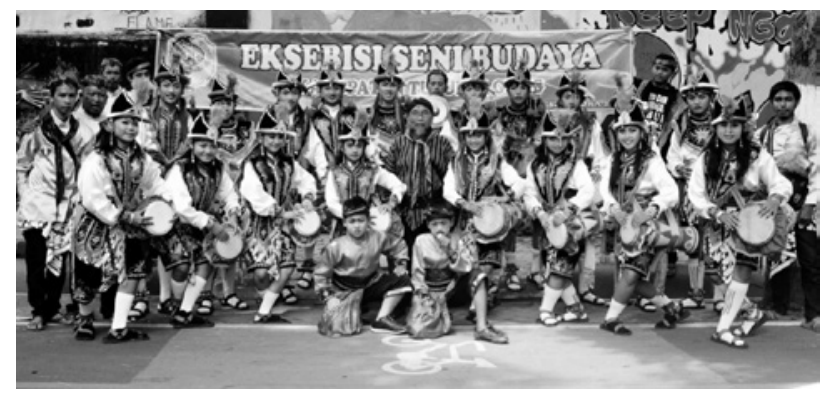

Gambar 1. Reog Tulungagung (2016) Cetak digital pada kertas doff $150 \times 72 \mathrm{~cm}$ 
dalam upaya pengenalan dan pengembangan Reog Tulungagung saat mewakili daerah dan mengenalkan Reog Tulungagung. Foto ini dipilih sebagai foto pembuka karena memuat segala aspek dari judul penciptaan ini, di mana Reog Tulungagung sebagai objek ditunjukan potret identitasnya yang digunakan oleh anggota dari Sanggar Tari Dandhang Saputro Mudho dengan Suratmin Wibisono sebagai pemimpin sanggar juga berada didalam foto ini.

Foto ini diambil dengan wide angle untuk mengambil secara keseluruhan potret dari anggota sanggar. Pemakaian bukaan diafragma kecil untuk menangkap fokus pada keseluruhan anggota, sedangkan pencahaayan yang dipakai dalah cahaya matahari.

Pesan lain yang dapat pada foto ini bahwa kebanyakan anggota yang berperan sebagai penari di sanggar ini memang masih muda dan rata-rata masih duduk di bangku sekolah. Ini merupakan proses pelestarian yang dilakukan Suratmin agar pada generasi berikutnya Reog Tulungagung tidak hilang.

Suratmin (65) mengerjakan pembuatan kendhang (gambar 2) pesanan atau untuk pementasan sanggarnya di gudang belakang rumahnya. Hampir sebagian besar waktu Suratmin habiskan ditempat ini. Selain membuat kendhang, pria kelahiran 1951 inijuga memperbaiki sendiri peralatan dan perlengkapan lain untuk pertunjukan sanggarnya. Dalam pembuatan satu buah

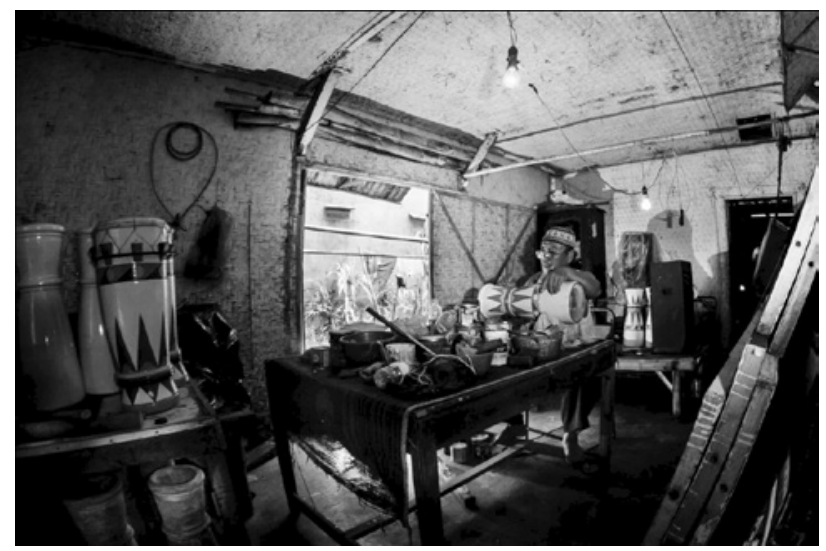

Gambar 2. Gudangan (2016) Cetak digital pada kertas doff $75 \times 50 \mathrm{~cm}$ dhodhog ini memakan waktu kurang lebih satu bulan dari bahan baku bentuk dasar sampai siap dipakai.

Foto ini memuat gambaran sosok atau potret dari Suratmin Wibisono sebagai pelaku seni dengan kesehariannya yang banyak dilakukan ditempat ini. Hal ini juga menunjukkan keseriusan Suratmin dalam mengembangkan Reog Tulungagung, karena sebagai kesenian yang baru dikenal dan tidak banyak diminati, hanya Suratmin yang membuat kendhang untuk Reog Tulungagung dan sering sekali mendapat pesanan kendhang yang menjadi pemasukan utama untuk keluarga dan menghidupkan kegiatan di dalam sanggar.

Foto ini menggunakan bantuan pencahayaan dari flash sebagai fill-in karena kondisi dalam ruangan yang gelap. Foto ini diambil secara wide angle dengan eye level agar terlihat suasana didalam gudang tempat Suratmin bekerja yang terbuat dari dinding anyaman bambu dan dengan perlengkapan yang dipakai dan juga beberapa hasil pekerjaan yang sudah selesai.

Grup formasi (gambar 3) campuran anak kecil berlatih reog di lapangan sekolah. Kegiatan latihan yang dilakukan setiap hari dalam seminggu sebelum pertunjukan harus dilakukan dari sore hari hingga malam, karena jumlah grup formasi yang banyak sehingga harus berlatih selain

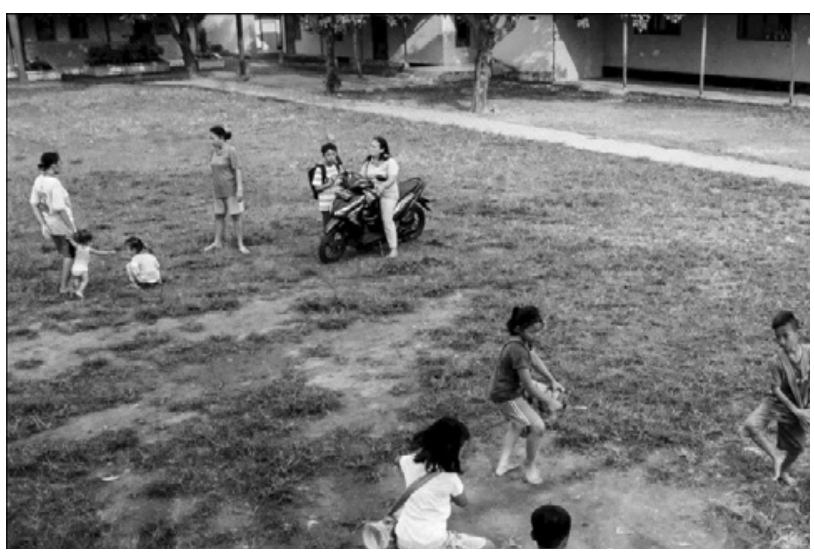

Gambar 3. Regenerasi Reog (2016) Cetak digital pada kertas doff $75 \times 50 \mathrm{~cm}$ 
dihalaman kelurahan, seperti di lapangan sekolah.

Foto ini diambil dengan entire dan angle dari atas untuk memperlihatkan formasi yang mereka lakukan saat berlatih dan membuat lebih sederhana background dengan memperluas bidang lapangan dan mengurangi bangunan kelas. Komposisi diagonal membuat foto lebih dinamis. Foto ini menggambarkan kegiatan anakanak saat berlatih reog untuk pementasan di lapangan sekolah dekat sanggar. Foto ini menunjukkan dedikasi dan niat yang kuat dalam berkesenian, meskipun harus membawakan Reog Tulungagung memakai kendhang reog orang dewasa untuk anakanak yang masih duduk disekolah dasar, mereka tetap berlatih dimanapun tempat yang bisa dipakai.

\section{SIMPULAN}

Konsep pembuatan karya berorientasi pada sosok seorang Suratmin Wibisono sebagai dasar acuan atau kerangka cerita pemahaman tentang eksistensi Reog Tulungagung yang dikembangkan di sanggar miliknya. Karya penciptaan fotografi dokumenter tentang Reog Tulungagung ini dalam proses penciptaannya juga membutuhkan persiapan. Persiapan yang dibuat meliputi pengumpulan data dan penyediaan peralatan untuk pemotretan. Pengumpulan data dapat menggunakan beberapa metode seperti, metode observasi di lingkungan Sanggar Tari Dandhang Saputro Mudho Tulungagung, metode wawancara dengan Kepala Dinas Kebudayaan Tulungagung, Suratmin Wibisono pemilik sanggar, para guru tari sanggar, para anggota penari Sanggar Dandhang Saputro Mudho, dan juga metode pustaka yang membahas kesenian Reog Tulungagung. Hasil karya foto dokumenter yang diciptakan berjumlah 20 karya foto tunggal. Setiap karya disusun sedemikian rupa sehingga membentuk sebuah narrative visual text.

Hasil pemilihan karya kegiatan yang paling banyak adalah kegiatan yang dilakukan di lingkungan sanggar Dandhang Saputro Mudho. Hal ini dikarenakan sanggar bukan hanya menjadi pusat berkegiatan seni, tetapi juga tempat anggota sanggar bermain dan bersosialisasi. Selain itu, lokasi sanggar yang juga berdekatan dengan rumah Suratmin dan beberapa anggota sanggar. Pemilihan karya tidak melulu kegiatan dalam sanggar, tetapi juga aplikasi dari latihan sanggar dan sisi lain dalam pelestarian yang dilakukan Suratmin.

Dalam proses produksi foto dokumenter ini ditemukan beberapa hambatan, yaitu kegiatan sanggar yang banyak dilakukan malam hari dan lokasi latihan yang minim pencahayaan serta kondisi cuaca yang tidak pasti membuat kegiatan mendadak ditiadakan membuat agak kesulitan untuk melakukan pemotretan namun setelah dilakukan beberapa kali pemotretan akhirnya berhasil merekam beberapa kegiatan latihan padamalam hari. Hambatan lain dari penciptaan ini adalah anggota sanggar yang terbuka dan merasa terganggu dengan keberadaan fotografer pada awal pemotretan, terutama pemakaian flash. Selain itu hambatan yang dialami adalah kegiatan reog baik dalam latihan maupun penampilan sangat jarang dimainkan karena memang kurang diminati. Akan tetapi, setelah melakukan pendekatan secara berulangulang selama proses pembuatan karya penulis berusaha memahami seluk beluk kesenian bagi para anggota dengan cara tinggal bersama di rumah Suratmin dan beberapa anggota sanggar, serta ikut melangsungkan kegiatan yang mereka lakukan hingga akhirnya mendapat kepercayaan dari pihak sanggar. Melalui kepercayaan yang telah diperoleh dari anggota sanggar, maka penulis lebih leluasa dalam pengambilan gambar. 


\begin{abstract}
Dalam proses penciptaan karya fotografi dokumenter terutama fotografi dokumenter diperlukan perencanaan yang matang, peralatan, survey lokasi, observasi, sampai pada proses penciptaan. Dengan perencanaan yang matang kendala-kendala di lapangan tentunya akan dapat diatasi. Proses penciptaan selanjutnya berupa eksekusi karya foto. Pada proses eksekusi ini harus terjadi komunikasi yang baik antara fotografer dan objek penciptaan karya sehingga akan mempermudah dalam pencapaian penciptaan karya. Untuk pembuatan karya foto dokumenter dengan tema kebudayaan tradisional di sanggar baiknya mempelajari bahasa daerah setempat agar mempermudah komunikasi saat melakukan pemotretan. Selain itu, tata letak panggung dan penguasaan panggung saat pertunjukan juga perlu diperhatikan untuk dapat melakukan pengambilan gambar yang maksimal.
\end{abstract}

\title{
KEPUSTAKAAN
}

\section{Buku}

Bahari, Nooryan. Kritik Seni.Yogyakarta: Pustaka Pelajar. 2014.

Gani, Rita dan Ratri Rizki Kusumalestari. Jurnalistik Foto Suatu Pengantar. Bandung: Simbiosa Rekatama Media. 2003.

Nugroho, R. Amien. Kamus Fotografi. Yogyakarta: Andi. 2006.

Pemerintah Daerah Kabupaten Daerah Tingkat II Tulungagung. Reyog Tulungagung. Tulungagung. 2009.

Pusat Bahasa Departemen Pendidikan. Kamus Besar Bahasa Indonesia. Jakarta: Gramedia Pustaka Utama. 2008.

Royce, Anya Peterson. Antropologi Tari terjemahan: F.X. Widaryanto. Bandung: Sunan Ambu PRESS STSI Bandung. 2007. 